\title{
The Role of Presenilin and its Interacting Proteins in the Biogenesis of Alzheimer's Beta Amyloid
}

\author{
Giuseppe Verdile $\cdot$ Samuel E Gandy • \\ Ralph N. Martins
}

Accepted: 1 August 2006/Published online: 31 August 2006

(C) Springer Science+Business Media, Inc. 2006

\begin{abstract}
The biogenesis and accumulation of the beta amyloid protein $(\mathrm{A} \beta)$ is a key event in the cascade of oxidative and inflammatory processes that characterises Alzheimer's disease. The presenilins and its interacting proteins play a pivotal role in the generation of $A \beta$ from the amyloid precursor protein (APP). In particular, three proteins (nicastrin, aph-1 and pen-2) interact with presenilins to form a large multi-subunit enzymatic complex ( $\gamma$-secretase) that cleaves APP to generate A $\beta$. Reconstitution studies in yeast and insect cells have provided strong evidence that these four proteins are the major components of the $\gamma$-secretase enzyme. Current research is directed at elucidating the roles that each of these protein play in the function of this enzyme. In addition, a number of presenilin interacting proteins that are not components of $\gamma$-secretase play important roles in modu-
\end{abstract}

Special issue dedicated to John P. Blass.

G. Verdile $\cdot$ R. N. Martins $(\bowtie)$

Centre of Excellence for Alzheimer's disease Research and Care, and the Sir James McCusker Alzheimer's Disease Research Unit, School of Exercise, Biomedical and Health Sciences, Edith Cowan University, 100 Joondalup Drive, Joondalup 6027 WA, Australia

e-mail: r.martins@ecu.edu.au

G. Verdile $\cdot$ R. N. Martins

Hollywood Private Hospital, Nedlands, WA, Australia

G. Verdile $\cdot$ R. N. Martins

School of Psychiatry and Clinical Neurosciences, University

of Western Australia, Crawley, WA, Australia

S. E Gandy

Farber Institute for Neurosciences, Thomas Jefferson

University, Philadelphia, PA, USA lating $\mathrm{A} \beta$ production. This review will discuss the components of the $\gamma$-secretase complex and the role of presenilin interacting proteins on $\gamma$-secretase activity.

Keywords Alzheimer's disease $\cdot$ Amyloid precursor protein $\cdot$ Beta amyloid $\cdot$ Presenilin $\cdot$ Interacting proteins $\cdot$ Gamma secretase
Abbreviations
APP amyloid precursor protein
A $\beta \quad$ beta amyloid
AICD APP intracellular domain
aph-1 anterior pharynx defective 1
pen-2 presenilin enhancer 2
PS1 presenilin 1
PS2 presenilin 2
TMP21 transmembrane protein 21

\section{Introduction: the generation of beta amyloid by presenilin and its binding proteins}

Alzheimer's disease (AD) is a complex, progressive neurodegenerative disorder that is neuropathologically characterised by extensive neuronal loss and the presence of neurofibrillary tangles and senile plaques. While the majority of AD cases are sporadic, $\sim 5 \%$ of AD cases are familial (FAD) with mutations in three genes, amyloid precursor protein, presenilin 1 (PS1) and presenilin 2 (PS2) accounting for the majority of cases. A major feature of both sporadic and familial forms of $\mathrm{AD}$, is the accumulation and deposition of a small peptide referred to as beta amyloid $(\mathrm{A} \beta)$ within 
brain tissue of $\mathrm{AD}$ sufferers. The mechanisms that underlie the disease processes are poorly understood. However, the accumulation of $A \beta$ is thought to play a pivotal role in neuronal loss or dysfunction through a cascade of events that include the generation of free radicals, mitochondrial oxidative damage and inflammatory processes (reviewed in Refs. [1, 2]). The primary event that results in the abnormal accumulation of $A \beta$ is thought to be the dysregulated proteolytic processing of its parent molecule, the amyloid precursor protein (APP).

The APP molecule is a transmembrane glycoprotein that is proteolytically processed by two competing pathways, the non-amyloidogenic and amyloidogenic (A $\beta$ forming) pathways. How these pathways are regulated remains unclear. However, there are many factors including diet, hormonal status, and genetic mutations that influence the processing of APP to generate $A \beta$ (reviewed in Refs. [1, 3]). Three major secretases are postulated to be involved in the proteolytic cleavage of APP. These include $\alpha$-secretase (of which the metalloproteases ADAM17/TACE and ADAM 10 are likely candidates), beta APP cleaving enzyme (BACE, formally known as $\beta$-secretase) and the $\gamma$-secretase. The $\alpha$-secretase cleaves within the A $\beta$ domain of APP thus precluding the formation $A \beta$ and generating non-amyloidogenic fragments and a secreted form of APP ( $\alpha$-APPs). In the amyloidogenic pathway (Fig. 1), BACE cleaves near the $\mathrm{N}$-terminus of the A $\beta$ domain on the APP molecule, liberating another soluble form of APP, $\beta$-APPs and a C-terminal fragment (C99) containing the whole $A \beta$ domain. The final step in the amyloidogenic pathway is the intramembranous cleavage of the C99 fragment by $\gamma$-secretase, to liberate the $A \beta$ peptide (reviewed in Ref. [1]). Identification of multiple cleavage sites within the APP molecule has suggested the presence of other secretases, namely $\epsilon$ - and $\zeta$-secretase; that generate the APP intracellular domain (AICD) and a longer fragment of $\mathrm{A} \beta$ (A $\beta 46)$, respectively [4-7]. Although different enzymes may exists, the same $\gamma$-secretase complex that generates $A \beta$ may also generate AICD and A $\beta 46$ as these products are inhibited by $\gamma$-secretase inhibitors [4-7] indicating that this enzyme has multiple cleavage sites. However, over-expression and mutagenesis studies have shown that the production of $A \beta$ and AICD may be independent catalytic events $[8,9]$.

The $\gamma$-secretase enzyme is thought to be an aspartyl protease that has the unusual ability to regulate intramembrane proteolysis (RIP) for a growing list of type 1 integral membrane proteins which include, APP, APP like proteins (APLPs), E-Cadherin, CD44, lipoprotein receptor related protein (LRP), Notch, sterol regula- tory element-binding protein (SREBP), interferon response element (IRE1) and activated transcription factor 6 (ATF-6) (for recent review see [10]). The mechanism of RIP and $\gamma$-secretase activity is unknown. However a transient hydrophilic environment for catalysis within the lipid membrane must be created. Furthermore, the enzyme (or an enzyme domain) must have the ability to bend and unwind the $\alpha$-helical substrates, exposing their amide bonds to hydrolysis. It is therefore conceivable that the $\gamma$-secretase enzyme is an integral protein of the lipid bi-layer and contains a number of proteins that may have different functions within an enzyme complex. The exact conformation or molecular architecture of the $\gamma$-secretase enzyme remains unknown. However, large molecular mass complexes of $\sim 250 \mathrm{kDa}[11,12], \sim 500 \mathrm{kDa}[13-17]$ and $\sim 2,000 \mathrm{kDa}[13,18]$ have been identified.

Over the last few years biochemical and genetic approaches have identified four components of the $\gamma$ secretase complex, presenilins, nicastrin, anterior pharynx defective (aph-1) and presenilin enhancer 2 (pen-2). Over-expression and expression knockdown studies have provided strong evidence that these proteins are essential for $\gamma$-secretase activity [15, 19-24]. Subsequent reconstitution studies in non-mammalian cells have provided evidence that these are the only components responsible for $\gamma$-secretase catalytic activity [25-27]. However the active component and the active catalytic site of this enzymatic complex are yet to be identified.

\section{The roles of presenilin and its binding partners within the $\gamma$-secretase complex in A $\beta$ generation}

Presenilin 1: the catalytic component of the $\gamma$-secretase enzyme

Presenilin 1 (PS1) is thought to be the most critical component of the $\gamma$-secretase complex as evidence indicates that it is the catalytic component of this proteolytic enzyme. The finding that mutations in PS1 account for the majority of inherited early onset forms of $\mathrm{AD}$ and result in the overproduction of the highly amyloidogenic A $\beta 42$ [28-30] provided the initial evidence that PS1 facilitates $\gamma$-secretase activity. Subsequent studies showed that PS1 ablation or mutagenesis of two highly conserved aspartate residues within transmembrane domains 6 and 7 of PS1 results in a reduction in $A \beta$ levels [31-34]. Furthermore, aspartyl protease inhibitors and transition state analogue inhibitors which are designed to target the active site of the protease, all reduce $A \beta 40$ and $A \beta 42$ levels and have 
Fig 1 Formation of the $\gamma$ secretase complex and $A \beta$ generation. A schematic representation of the proposed formation of the $\gamma$ secretase complex and the enzymatic activity resulting in $\mathrm{A} \beta$ generation. Evidence has been provided to show that PS, nicastrin (NCT), aph-1, and pen- 2 are the only components of the $\gamma$-secretase complex. Nicastrin and aph-1 are involved in the early formation of the complex, interacting with each other and forming a dimeric subcomplex. The presenilin holoprotein is incorporated into the aph-1: NCT subcomplex, nicastrin undergoes post-translational modifications and the complex is transported to the cell surface (or other $A \beta$ generating compartments, i.e. TGN) as a trimeric complex. Pen-2 is incorporated into the complex and presenilin is cleaved forming the active $\gamma$ secretase complex. Following cleavage of APP by BACE to liberate secreted APP, the APP-C99 fragment left embedded within the membrane undergoes regulated intramembranous processing (RIP) by the $\gamma$ secretase complex, liberating $\mathrm{A} \beta_{1-40}$ or $\mathrm{A} \beta_{1-42}$ (Modified from Ref. [165])
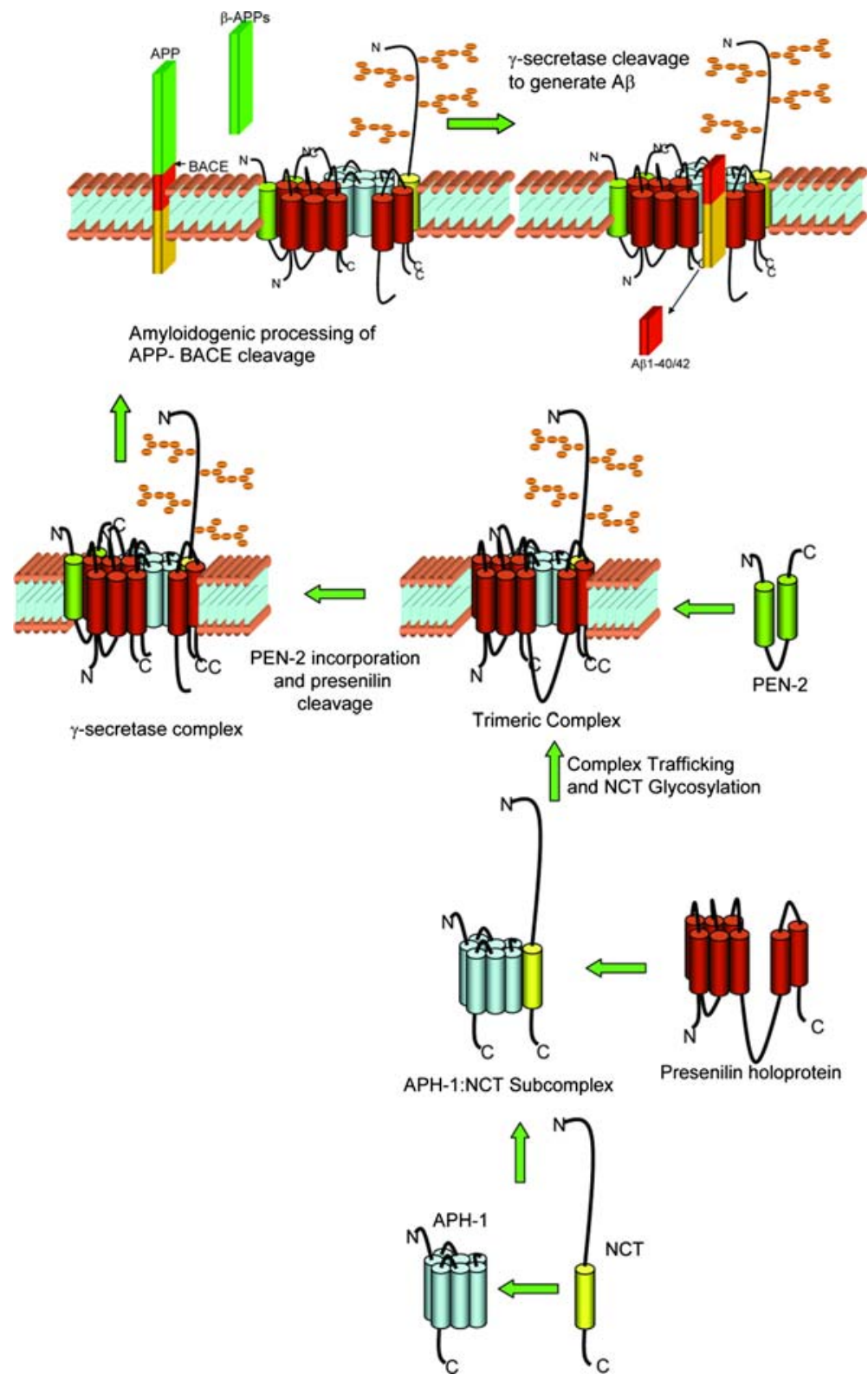

been shown to affinity label and bind to PS1 [35-37]. In addition, physical interactions between PS1 and the APP-C99 fragment have been identified [38-40]. The studies outlined above provide substantial evidence to indicate that PS1 is the catalytic subunit of $\gamma$-secretase. However, this transmembrane protein is not typical of a conventional aspartyl protease, and lacks the typical $\mathrm{D}(\mathrm{T} / \mathrm{S}) \mathrm{G}$ motif for an aspartyl protease active site (recently reviewed in [41]. Aspartyl proteases require the presence of two aspartate residues for the hydrolysis of the peptide bond. Although PS1 lacks the typical $\mathrm{D}(\mathrm{T} / \mathrm{S}) \mathrm{G}$ aspartyl protease active site it does contain the two aspartyl residues (D257 and D385) which are either critical for the active site on the $\gamma$-secretase complex or constitute the active site [42]. Other proteases that contain atypical aspartyl protease motifs and have weak homology with PS1 include the bacterial membrane embedded aspartyl protease, type 4 prepilin protease and the signal peptidases, which are all transmembrane proteins. These proteins share the unusual aspartyl motif GxGD and perform intramembranous cleavage of type I membrane proteins (reviewed in [43]). The topology and atypical characteristics of these proteins make them an unprecedented class of protease and as is the case for PS1, would require interaction with of other proteins within the complex.

The interaction between the components of the $\gamma$-secretase complex is not sufficient to create a macromolecular enzyme complex such as $\gamma$-secretase (i.e. total mass of all the components is $\sim 200 \mathrm{kDa}$ ). Thus, 
dimer or trimer formation must occur within the complex. To date the only member of the complex that is known to undergo this process is PS1. The full length PS1 protein is rapidly endoproteolytically cleaved within its characteristic large hydrophilic loop into amino- and carboxy-terminal fragments (NTF/CTF) of $\sim 27$ and $\sim 17 \mathrm{kDa}$, respectively [44, 45]. These fragments are thought to interact with each other to form the catalytic component of the $\gamma$-secretase enzyme since in the absence of full length PS1, co-expressed NTF and CTF were able to generate $\gamma$-secretase activity in presenilin deficient mammalian cells [46, 47]. The stoichiometry and the nature of the interaction between these fragments remain unclear. It has been shown by many studies that the NTF:CTF form a heterodimer in mammalian cells [12, 48-51] leading to suggestions that this heterodimer is the active $\gamma$-secretase [52]. However, Cervantes and colleagues [53] provided evidence that the presenilin fragments can form a tetramer by identifying heterodimers as well as NTF and CTF homodimers in yeast. Evidence for heterodimer and NTF homodimer (but not CTF homodimer) formation has been provided by photoaffinity labelled cross-linking studies [54]. This formation provides a core of aspartyl residues required for aspartyl protease activity. However, it has yet to be established whether the hypothetical "core" is formed between fragments from one PS1 molecule or multiple molecules within the complex. Further, if PS1 is the "catalytic core" of the $\gamma$-secretase complex the roles of the other interacting proteins need to be determined.

Nicastrin: the substrate docking site and scaffolding for building the $\gamma$-secretase complex

Nicastrin was discovered to be part of the $\gamma$-secretase complex when it was found to co-immunoprecipitate with PS1 [55]. Nicastrin is a type I transmembrane protein with a 670 amino acid long hydrophilic N-terminal domain, a transmembrane domain, and a relatively short cytoplasmic C-terminus of twenty amino acid residues [55]. The protein undergoes glycosylation and sialylation within the secretory pathway to yield a mature $\sim 150 \mathrm{kDa}$ protein, the largest component of the $\gamma$-secretase complex [14], [56-58]. Nicastrin has been shown to be a critical component of the $\gamma$-secretase complex as inhibition of nicastrin function in vitro and in vivo results in a complete loss of APP and Notch cleavage [14, 55, 59-61]. Within this complex, nicastrin appears to be involved in the early formation of the complex, particularly in the formation of the first subcomplex between itself and aph-1 (Fig. 1). Recent evidence suggests that nicastrin is critical for the cor- rect assembly of the $\gamma$-secretase complex within the endoplasmic reticulum and the intracellular trafficking of the complex to the cell surface $[62,63]$. Furthermore, nicastrin is essential for the interaction between the complex and APP-C99 and thus may act as a receptor for $\gamma$-secretase substrates $[63,64]$. Therefore, although nicastrin is a critical component, evidence to date suggests that it is unlikely to be a catalytic component of the $\gamma$-secretase complex. Instead, nicastrin acts as a scaffold for the building of the active complex, and a possible substrate docking site.

Anterior pharynx defective 1 (aph-1): scaffolding partner for nicastrin and may have possible catalytic activity

The aph- 1 protein is a $\sim 30 \mathrm{kDa}, 308$ amino acid long 7-transmembrane protein [65] existing in two homologous forms, located on chromosome 1 and chromosome 15 (aph-1a \& aph-1b respectively; [19]). In addition, as the result of alternate splicing, a long and short isoform of aph-1a have also been reported, with the short isoform more abundantly expressed in most tissues [21]. Although the exact function of these isoforms remains unknown, multiple $\gamma$-secretase complexes containing aph-1 isoforms are thought to exist $[66,67]$. The aph-1a isoform appears to be incorporated into active $\gamma$-secretase complexes. Deletion of aph-1a causes a reduction in $A \beta$ generation [66] and is the major isoform present in $\gamma$-secretase complexes during embryonic development [67]. The $\gamma$-secretase complexes incorporating aph-1b are thought to have a redundant function as aph-1b has been found not to be involved in the regulation of other $\gamma$-secretase components or $\gamma$-secretase activity [66].

The aph-1 protein forms a stable and intermediate $\sim 140 \mathrm{kDa}$ complex with Nicastrin, before binding PS1. Aph-1 has been shown to interact with immature and mature forms of presenilins and nicastrin [21]. The GXXXG motif located within transmembrane 4 of aph1 has been shown to be important in this interaction [68], [69]. The aph-1: nicastrin sub-complex appears to play a role in the stabilisation and assembly of PS1 in the $\gamma$-secretase complex (Fig 1; [24, 70, 68]). However, the exact role of aph- 1 in the $\gamma$-secretase complex remains unknown. Expression studies have shown that removal of aph-1 destabilises the presenilin holoprotein and the addition of aph-1 leads to the accumulation of the holoprotein [11, 19-24, 71]. Thus together with nicastrin, aph-1 is thought to contribute the initial formation and trafficking of the $\gamma$-secretase complex and thereby provide a scaffold for the proteolytic processing of PS1 and the formation of the active site. 
Aph-1 is critical for the activity of the fully constructed $\gamma$-secretase complex. Evidence has been provided that as well as binding to immature components of $\gamma$-secretase in early stages of complex formation, aph-1 also interacts with the mature forms of PS1, nicastrin and pen-2 [68, 72]. Furthermore, recent evidence has been provided to suggest that this interaction occurs on the cell surface where it also binds the $\gamma$-secretase substrate, Notch and facilitates its cleavage [72]. These studies suggest that apart from the scaffolding function it shares with nicastrin, aph-1 has another function within the fully constructed, active $\gamma$-secretase complex. Structural and functional similarities between aph- 1 and other proteases that possess the ability for intramembranous cleavage (such as rhomboid, [68, 73] suggests that this transmembrane protein may have an enzymatic function within the complex. This postulated novel function for aph-1 needs to be validated by future studies.

Presenilin Enhancer 2 (pen-2): the elusive presenilinase or "molecular clamp" that holds the complex together?

The pen-2 protein is a $\sim 12 \mathrm{kDa}, 101$ amino acid long protein containing two transmembrane domains and its $\mathrm{N}$ - and C-terminals facing the lumen of the endoplasmic reticulum [74, 75]. Pen-2 has been shown to interact with Nicastrin, aph-1, and also PS1. Without this interaction pen-2 has been shown to be degraded, possibly by the proteasome $[76,77]$. Ablation of pen-2 results in significantly reduced PS1 endoproteolysis and A $\beta$ production, suggesting that pen- 2 is essential for both presenilinase and $\gamma$-secretase activity $[15,19,22-$ 24]. Likewise, combinational expression studies have shown that when pen-2 is co-expressed with the other components of the $\gamma$-secretase complex in a step-wise manner, endoproteolysis of the PS1 holoprotein was enhanced [11, 22, 24-27, 71]. A trimeric sub-complex between presenilin, nicastrin and aph-1 has been identified in cells lacking pen-2 [24, 70] suggesting that pen-2 may be the final protein incorporated into the $\gamma$ secretase complex (Fig. 1). Recent evidence has suggested that pen-2 is incorporated into the $\gamma$-secretase complex through an interaction with presenilins. The "DYLSF" domain of pen-2 and a "NF" motif on transmembrane 4 of PS1 have been shown to be critical for the interaction between these proteins [78-80]. The cleavage of PS1 occurs within the hydrophilic loop and is distal from the interaction site on transmembrane 4, suggesting that another domain of pen-2 is responsible for the cleavage of PS1 or pen-2 may present PS1 to the elusive "presenilinase" which may be another member of the $\gamma$-secretase complex. The C-terminal end of pen2 has been shown to be important for $\gamma$-secretase activity since altering the length of this region by addition or deletion of residues has been shown to reduce $A \beta 40$ and 42 generation without altering the binding of pen-2 to the complex [78] suggesting that pen-2 may have an alternative function within the complex. One suggestion put forward by Hasegawa and colleagues [78] is that the C-terminus of pen-2 may be a linker/space molecule that maintains spatial interactions between proteins within the complex. However, recent evidence using pen-2 C-terminal loss of function mutations suggest that the $\mathrm{C}$-terminus acts as a "molecular clamp" holding together the presenilin fragments and the whole $\gamma$-secretase complex [81]. If this is the case then PEN-2 is an integral part of the catalytic process holding the complex together whilst the $\gamma$-secretase products are generated.

The newest member of the complex: TMP21, a modulator of $\gamma$-secretase activity

Recently another member of the $\gamma$-secretase complex was immuno-purified from wild-type PS1 and PS2 blastocyte derived cells [82]. The type 1 transmembrane protein termed TMP21 is a member of the p24 cargo-family which may have a signalling role in the sorting and transport of proteins from the endoplasmic reticulum to the Golgi $[83,84]$. It was shown by Chen and colleagues [82] that TMP21 is a member of the complex as it was isolated in a high molecular weight presenilin complex, interact with all of the known components of the $\gamma$-secretase complex, co-localised with the complex components in the ER, Golgi and cell surface and destabilised from the complex in the absence of the presenilins and pen-2. Although the over-expression of TMP2 1 did not alter $\gamma$-secretase activity, its suppression resulted in and increase in $A \beta 40$ and $A \beta 42$. However, suppression of TMP21 did not alter the production of AICD, notch cleavage to generate NICD or cleavage of E-cadherin to generate CICD. These results are consistent with the notion that $\gamma$ - and $\epsilon$-secretase cleavage activities are independently regulated and indicate a role for TMP21 in modulating $\gamma$-secretase activity to generate $A \beta$. This role for TMP21 appears to be independent of its role in protein transport since the suppression of both TMP21 and p24a (a member of the p24 cargo family that interacts with TMP21) does not result in additional increases in A $\beta$ production to that observed following the suppression of TMP21 only [82]. This finding led the authors to postulate that there are two pools of TMP21, a major pool that is stabilised by, p24a and has 
no role in $A \beta$ production and a minor pool that modulates $A \beta$ production, independent of $\mathrm{p} 24 \mathrm{a}$. Although, further investigation is required to determine the precise mechanism of action, it appears that TMP21 may function to regulate intramembrane proteolysis controlling $\gamma$-secretase activity and thus preventing the over-production of A $\beta$. This modulator role for TMP21 is important to consider when elucidating mechanisms on how $\gamma$-secretase activity is altered (for example by presenilin mutations) resulting in enhanced $A \beta 40$ and A $\beta 42$ production.

Presenilin 2 (PS2): capable of forming a fully functional $\gamma$-secretase complex

The presenilin proteins share an overall homology of $67 \%$ with the highest similarities in the predicted transmembrane domains. Fewer similarities are found at the N-terminus and in the central region of the hydrophilic loop [85, 86]. Although there are some structural similarities between PS1 and PS2 several lines of evidence suggest that these proteins may have distinct functions. Mice lacking PS1 die before birth and have severe skeletal and brain deformities, whilst those lacking PS2 only develop a mild pulmonary fibrosis and haemorrhage with age [33, 87-90]. Compared to neuronal cultures isolated from PS1 ablated mice, those isolated from PS2 knockout mice exhibit higher $\mathrm{A} \beta$ production and are less sensitive to $\gamma$-secretase inhibitors [89, 91]. Lai and colleagues [91] also provided evidence to suggest that distinct PS1 containing and PS2 containing complexes exist [91]. If this is the case, evidence to date suggests that PS2 containing complexes have different functions and have less $\gamma$-secretase processing power than PS1 containing complexes. However, recent in vitro evidence has suggested that chimeras of PS1 and PS2 fragments retain $\gamma$-secretase activity [92] suggesting that active complexes containing both PS1 and PS2 could occur. However, this is unlikely to occur in vivo as PS2 and PS1 transgenic mice have differential effects on $\gamma$-secretase activity [93]. In this study mice lacking PS1 were crossbred with transgenic mice containing wild type or mutant PS2/PS1. Compared to mice harbouring wildtype PS1, those harbouring wild-type PS2 had a $\sim 4$-fold reduction in $\mathrm{A} \beta 40$ and $\sim 2$-fold reduction $\mathrm{A} \beta 42$ brain levels. In addition, the authors reported that although mutations in PS1 lead to higher brain levels of A $\beta 40$ and $\mathrm{A} \beta 42$ than PS2 mutations, those mice harbouring PS2 mutations had higher brain levels of $A \beta 42$, whilst A $\beta 40$ brain levels remain unchanged [93]. Taken together these studies suggest that PS1 containing complexes predominate in generating $A \beta 40$ and $A \beta 42$.
However, the finding that PS2 is involved in $\mathrm{A} \beta 42$ (but not $A \beta 40)$ generation suggests that two $A \beta$ generating $\gamma$-secretase complexes $(\gamma$-40 secretase and $\gamma$ - 42 secretase) exist, with $\gamma-42$ secretase complexes containing both PS1 and PS2.

\section{The roles of presenilin binding proteins not incorporated into the active $\gamma$-secretase complex}

In addition to $A \beta$ generation, the presenilins have been implicated in a variety of intracellular processes including membrane trafficking, Notch signalling, neuronal plasticity, cell adhesion, regulation of calcium homeostasis, the unfolded protein response, and apoptosis. Therefore it is not surprising that the presenilins have a growing list of binding partners (see Table 1). Though the presenilin binding proteins that are incorporated into the $\gamma$-secretase complex are critical for the activity of this enzyme, those that are not integral components have equally important roles in modulating $A \beta$ production. A number of non-complex presenilin binding proteins have been shown to alter $\gamma$-secretase activity (see Table 1 ). However, only a few have had supporting evidence that their direct interaction with the presenilins modulate $\gamma$-secretase activity. These are described below and shown in Fig. 2.

\section{Calsenilin}

Calsenilin (also called DREAM or kChIP3) is a calcium binding protein, that was first identified through yeast two hybrid screening using the PS2 C-terminus as the bait protein [94]. The interaction between calsenilin and the presenilins appear to have a role in APP processing. It was initially demonstrated that calsenilin can form a complex with PS1 and PS2 and regulate presenilin fragment formation in mammalian cells [95]. This study also showed that calsenilin may facilitate presenilin mediated apoptosis, since calsenilin was shown to preferentially interact with the C-terminal fragment of PS2 that results from caspase cleavage of the presenilin holoprotein [96]. Expression studies in vivo (Xenopus) and in vitro (mammalian cells) have shown that the interaction between presenilin and calsenilin may be involved in ER calcium release and apoptosis [97, 98]. Over-expressing calsenilin in neuronal cells resulted in cell death which was enhanced by the co-expression of wild-type or PS1 mutations [99]. These studies have suggested that the interaction between calsenilin and presenilins may function in apoptotic pathways. However, several lines of evidence 
Table 1 Presenilin interacting proteins

\begin{tabular}{|c|c|c|c|}
\hline Interacting protein & Proposed function & $\begin{array}{l}\text { Interaction with } \\
\text { presenilins shown } \\
\text { to modulate } A \beta \\
\text { production }\end{array}$ & Reference \\
\hline \multicolumn{4}{|l|}{ Complex components } \\
\hline APH-1 & $\begin{array}{l}\text { Component of the } \gamma \text {-secretase complex; role for initial } \\
\text { formation of the complex, or a proteolytic role }\end{array}$ & Yes & {$[19,65,67,123]$. } \\
\hline Nicastrin & $\begin{array}{l}\text { Component of } \gamma \text {-secretase complex; possible role } \\
\text { as a receptor for APP-C } 99\end{array}$ & Yes & {$[14,55-58]$} \\
\hline PEN-2 & $\begin{array}{l}\text { Component of the } \gamma \text {-secretase complex, role in } \\
\text { proteolytic cleavage of the presenilins }\end{array}$ & Yes & {$[19,24,70,76,77]$} \\
\hline TMP21 & $\begin{array}{l}\text { Recently identified component of the } \gamma \text {-secretase } \\
\text { complex, role in modulating } A \beta \text { production }\end{array}$ & Yes & {$[82]$} \\
\hline \multicolumn{4}{|l|}{$\gamma$-secretase substrates } \\
\hline APP-C99 & $\begin{array}{l}\text { Substrate for the } \gamma \text {-secretase complex: } \\
\text { precursor to } A \beta \text { generation }\end{array}$ & Yes & {$[38-40]$} \\
\hline $\mathrm{E} / \mathrm{N}$ cadherin & $\gamma$-secretase substrate; role in Cell-Cell Adhesion & No & {$[124]$} \\
\hline IRE1 & $\gamma$-secretase substrate; role in unfolded protein response & No & {$[125,126]$} \\
\hline LRP & $\gamma$-secretase substrate; Lipid metabolism & Yes & [119] \\
\hline Notch1 & $\gamma$-secretase substrate; precursor to NICD generation & Yes & [112] \\
\hline \multicolumn{4}{|l|}{ Interacting binding proteins } \\
\hline ABP-280, Filamin homolog1 & Actin binding protein & No & [127] \\
\hline Bcl-2 & Anti-apoptotic molecule & No & [128] \\
\hline $\mathrm{Bcl}-\mathrm{X}_{\mathrm{L}}$ & Anti-apoptotic molecule & No & [129] \\
\hline Calmyrin & Possible calcium-myrstol switch & No & {$[130]$} \\
\hline CALP- calsenilin like protein & Novel member of the calsenilin/KChIp protein family & No & [131] \\
\hline Calsenilin & Calcium binding protein & Yes & {$[94,96-99,101,102]$} \\
\hline CLIP-170 & Linking membrane organelles to microtubules & No & {$[132]$} \\
\hline DRAL & LIM-domain containing protein & No & {$[133]$} \\
\hline FHL2 & Role in PI3K/Akt activation & No & {$[134]$} \\
\hline FKBP38 & Role in mitochondria mediated apoptosis & No & {$[135]$} \\
\hline Go & Signalling molecule & No & [136] \\
\hline GSK3 $\beta$ & Wnt signalling, serine threonine protein kinase & No & {$[137]$} \\
\hline HC5/ZETA & Subunits of the catalytic $20 \mathrm{~S}$ proteasome & Yes & {$[138]$} \\
\hline Met1 & Putative methyltransferase & No & [139] \\
\hline $\begin{array}{l}\text { Modifier of cell adhesion } \\
\text { protein (MOCA) }\end{array}$ & Regulates proteasomal activity on APP & Yes & {$[140]$} \\
\hline $\mathrm{Omi} / \mathrm{HtrA} 2$ & Serine protease, proapoptotic & No & {$[141]$} \\
\hline PAG & Neuronal proliferation protein & No & {$[142]$} \\
\hline PAMP and PARL & Metalloproteases & No & [143] \\
\hline PKA & $\begin{array}{l}\text { Serine/Theronine protein kinase; } \\
\beta \text {-catenin phosphorylation }\end{array}$ & No & {$[144]$} \\
\hline Plakoglobin & Role in b-catenin/Tcf- 4 activity & No & {$[145]$} \\
\hline PLD1 & Phospholipid-modifying enzyme & Yes & {$[146]$} \\
\hline PSAP & PDZ like protein & No & {$[147]$} \\
\hline QM/Jif1 & Negative regulator of c-Jun & No & [148] \\
\hline Rab proteins & Vesicle mediated protein trafficking & Yes & {$[149,150]$} \\
\hline RyR2 & Cardiac ryanodine receptor & No & {$[151]$} \\
\hline SEL-10 & Ubiquitination of proteins & Yes & {$[152]$} \\
\hline Sorcin & Calcium binding regulator of ryanodine receptor & No & {$[153]$} \\
\hline Syntaxin $1 \mathrm{~A}$ & Synaptic plasma-membrane protein & No & {$[154]$} \\
\hline Syntaxin 5 & ER-Golgi vesicular transport & Yes & {$[155,156]$} \\
\hline Tau & Microtubule binding protein & No & {$[137]$} \\
\hline Telencephalin & Neuron specific adhesion molecule & No & {$[40]$} \\
\hline TPIP & Tetratricopeptide repeat-containing protein & No & {$[157]$} \\
\hline Ubiquilin & Ubiquitin domain-containing protein & No & {$[158-160]$} \\
\hline X11 family of proteins & Cytoplasmic adaptor proteins & Yes & {$[110,111]$} \\
\hline$\beta$-catenin $/ \delta$-catenin (NPARP) & Wnt signalling. Cell adhesion & No & {$[161-163]$} \\
\hline$\mu$-Calpain & Calcium-dependent thiol protease & No & {$[164]$} \\
\hline
\end{tabular}



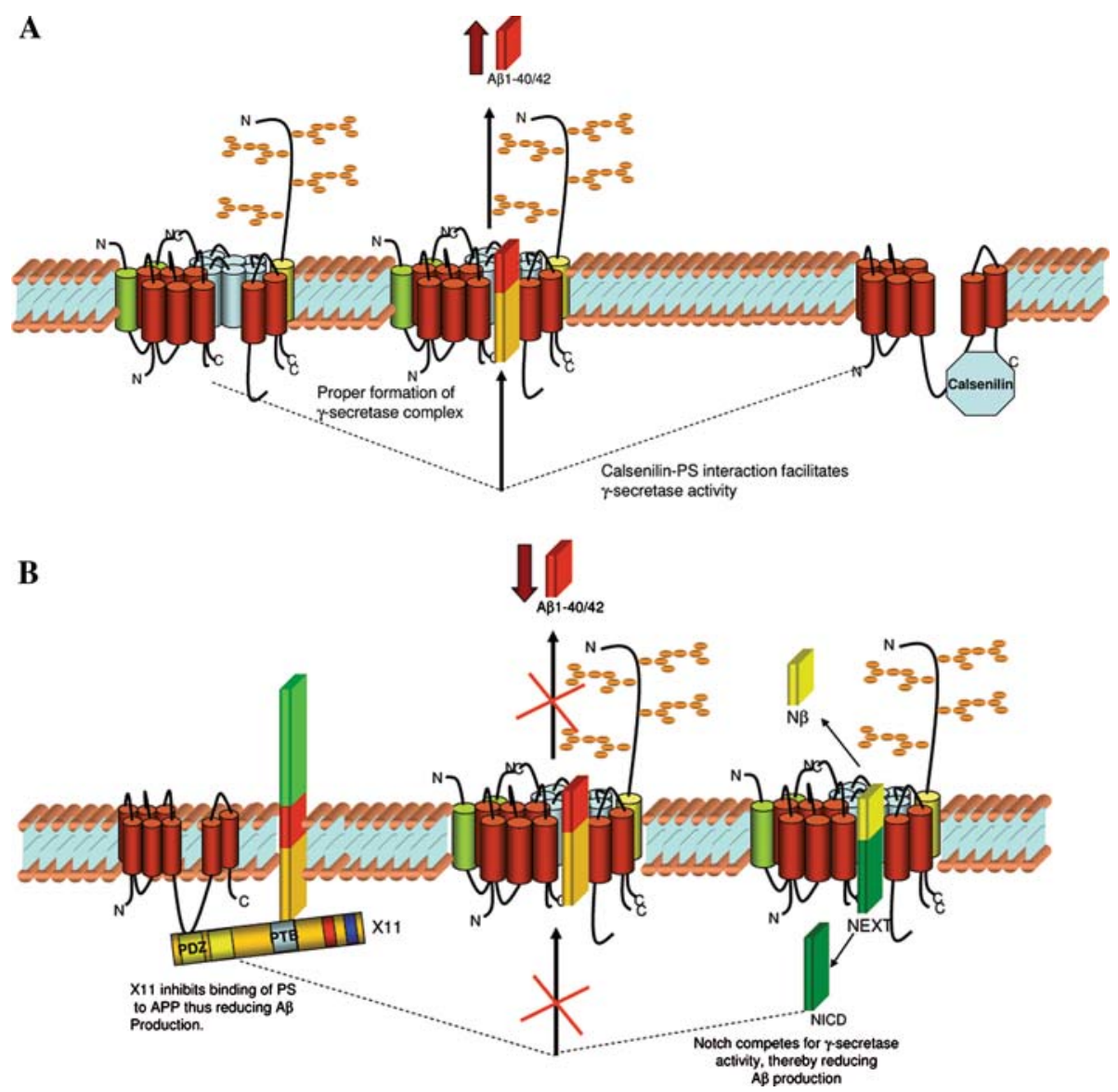

Fig. 2 The postulated roles for presenilin interacting proteins not incorporated into the $\gamma$-secretase complex in $\mathrm{A} \beta$ generation. A schematic representation of the postulated roles of presenilin interacting proteins in $(\mathbf{A})$ promoting or $(\mathbf{B})$ attenuating $\gamma$ secretase activity and $A \beta$ generation. (A) Together with the formation of the $\gamma$-secretase complex, calsenilin have been shown to interact with the presenilins and promote $\mathrm{A} \beta$ generation when over-expressed in mammalian cells. The role of calsenilin in $\mathrm{A} \beta$ generation remains unclear but maybe

suggest that calsenilin may also be implicated in APP processing and $A \beta$ generation. Initial in vitro studies showed that over-expression of calsenilin in mouse neuroblastoma cells resulted in a gene dose dependent accumulation of $\mathrm{A} \beta 42$ [100]. Using a $\gamma$-secretase luciferase based assay and a cell free system established by $\mathrm{Li}$ and colleagues [18] to characterise the $\gamma$ secretase complex in purified cell membranes, Jo and colleagues [101] recently reported that the overexpression of calsenilin resulted in an increase in $\gamma$ secretase activity. This calsenilin/presenilin, mediated activity was markedly reduced using a well-characterised $\gamma$-secretase inhibitor (L-685, 458). Furthermore, compared to wild-type mice, brain $A \beta 40$ and $A \beta 42$ levels were reduced in calsenilin ablated mice [102]. Together these studies would suggest that calsenilin has a second function, to facilitate $\gamma$-secretase activity. involved in the presentation of the substrate to the $\gamma$-secretase complex. (B) The presenilin interacting protein, X11 and other $\gamma$ secretase substrates that compete for enzyme activity such as Notch fragments (i.e. NEXT) have all been shown to reduce A $\beta$ generation when over-expressed in mammalian cells. X11 may reduce $A \beta$ production by binding to PS and APP preventing PS mediated cleavage of APP or its presentation to the $\gamma$-secretase complex

\section{X11/Mint proteins}

A family of cytoplasmic adaptor proteins called X11 (also known as munc-18-interacting proteins-mints) have also shown to have a direct role in APP processing. In particular, several studies have reported that X11 $\alpha$ and X11 $\beta$ stabilise APP and inhibit the secretion of $A \beta$ and APP from neuronal cells [103106]. The molecular mechanisms by which the $X 11 \mathrm{~s}$ influence APP processing and A $\beta$ production are not clear. However, this effect appears to be modulated by a direct interaction between X11 and APP. The interaction between the phosphotyrosine binding (PTB) domain within X-11 and the YENPTY motif within APP appears to modulate A $\beta$ generation, since introduction of point mutations within these domains enhanced A $\beta$ generation [103, 106-109]. The binding 
of X11 appears to stabilise APP, leading to its intracellular accumulation [103, 106-109]. It is conceivable that the X11-APP interaction may inhibit secretase accessibility to APP resulting in impaired $A \beta$ secretion. The X11 proteins have multiple binding domains and have been shown to interact with the PS1 C-terminal fragment through their PDZ domain [110]. The authors also showed an interaction between PS1 and APP in the presence of X11 that was otherwise ablated in the absence of X11. This suggests that an interaction between APP and PS1 is mediated through X11. A subsequent study has reported that $\mathrm{X} 11 \beta$ and alcadein (and X11ß-binding protein) expression prevents the binding of PS1 to APP [111]. The significance of the results from these interaction studies remains unclear. However, they do suggest that X11 proteins may act as inhibitory molecules preventing PS1 mediated proteolytic processing of APP and thus attenuating A $\beta$ production.

\section{Competing substrates}

Some presenilin binding proteins reduce the likelihood of $A \beta$ generation by competing for the catalytic activity offered by $\gamma$-secretase. One example is Notch1 which undergoes cleavage by $\gamma$-secretase to liberate an intracellular domain (NICD) that translocates to the nucleus where it co-activates transcription of genes involved in several developmental pathways [112-115]. The first evidence of substrate competition came from one study that treated neurons with the Noch1 ligand, delta, and found a dose dependent reduction in $A \beta$ levels [116]. In contrast, the over-expression of APP in these neurons resulted in a reduction in Notch signalling [116]. Further evidence for substrate competition was provided by Kimberley and colleagues [117] where APP and Notch based substrates directly competed for $\gamma$-secretase activity in a cell free assay. Similar results were achieved in a subsequent study where cells expressing Notch showed a reduction in $A \beta$ production [118]. Additional evidence for substrate competition has been provided recently for another substrate of $\gamma$ secretase, the cytoplasmic tail of the low-density lipoprotein receptor-related protein (LRP), which has also been shown to interact with PS1 [119]. The coexpression of the LRP C-terminal fragment and APP in $\mathrm{CHO}$ cells has been shown to result in a reduction in secreted levels of $A \beta 40$ and $A \beta 42$ [119].

Taken together, these studies not only suggest substrate competition but also the presence of a single $\gamma$-secretase. However, the presence of multiple $\gamma$-secretase complexes cannot be ruled out. As discussed above there is evidence in the literature for the formation of $\gamma$-secretase complexes with distinct functions. All of the studies described above are undertaken in conditions where there is a large amount of substrate available which could down-regulate the activity of one $\gamma$-secretase for another. Whether substrate competition occurs under physiological conditions and if there are certain conditions that promote a higher expression of one substrate over another remains to be determined.

\section{Concluding comments}

It is well established that together with presenilin, its binding proteins, nicastrin, aph- 1 and pen- 2 are the only proteins that constitute the $\gamma$-secretase complex responsible for generating A $\beta$ from APP. The function(s) of each $\gamma$-secretase component within the complex is gradually becoming apparent. However, there are many facets of $\gamma$-secretase activity that are yet to be identified such as the domain responsible for actual catalytic activity; the mechanisms of enzymatic activity within the lipid bi-layer; and the existence of single or multiple $\gamma$-secretase complexes. Further investigation using appropriate protein expression models and reconstitution studies such as those used to validate the protein components of $\gamma$-secretase complex is required to provide some insight into the processes that underlie the catalytic activity of this enzyme. Indeed, reconstitution of the $\gamma$-secretase complex in insect cells and purification of this complex from the cells have provided researchers with the first $3 \mathrm{D}$ images of the structure of this intricate enzyme [120,121]. Identification of the specific catalytic domain(s) within the complex would provide a site that could be a potential target to develop agents that specifically modulate $A \beta$ levels without altering the other known (and unknown) activities of the $\gamma$-secretase enzyme. Recent insight into this notion was provided by the finding that certain compounds selectively block the cleavage of APP but not Notch [122]. However, it is important to note that other presenilin interacting proteins not incorporated into the complex and the pathways they are involved in play important roles in APP processing and A $\beta$ generation. These interactions assist in many facets of $\gamma$-secretase activity, including modulating substrate/enzyme availability, and thus are important to consider when developing appropriate therapeutic strategies.

\section{References}

1. Verdile G, Fuller S, Atwood CS, Laws SM, Gandy SE, Martins RN (2004) The role of beta amyloid in Alzheimer's disease: still a cause of everything or the only one who got caught? Pharmacol Res 50:397-409 
2. Reddy PH (2006) Amyloid precursor protein-mediated free radicals and oxidative damage: implications for the development and progression of Alzheimer's disease. J Neurochem 96:1-13

3. Gandy S, Petanceska S (2001) Regulation of alzheimer beta-amyloid precursor trafficking and metabolism. Adv Exp Med Biol 487:85-100

4. Yu C, Kim SH, Ikeuchi T, Xu H, Gasparini L, Wang R, Sisodia SS (2001) Characterization of a presenilin-mediated amyloid precursor protein carboxyl-terminal fragment gamma. Evidence for distinct mechanisms involved in gamma-secretase processing of the APP and Notch1 transmembrane domains. J Biol Chem 276:43756-43760 Epub 42001 Oct 43752

5. Weidemann A, Eggert S, Reinhard FB, Vogel M, Paliga K, Baier G, Masters CL, Beyreuther K, Evin G (2002) A novel epsilon-cleavage within the transmembrane domain of the Alzheimer amyloid precursor protein demonstrates homology with Notch processing. Biochemistry 41:28252835

6. Zhao G, Mao G, Tan J, Dong Y, Cui MZ, Kim SH, Xu X (2004) Identification of a new presenilin-dependent zetacleavage site within the transmembrane domain of amyloid precursor protein. J Biol Chem 279:50647-50650

7. Zhao G, Cui MZ, Mao G, Dong Y, Tan J, Sun L, Xu X (2005) gamma-Cleavage is dependent on zeta-cleavage during the proteolytic processing of amyloid precursor protein within its transmembrane domain. J Biol Chem 280:37689-37697

8. Bergman A, Religa D, Karlstrom H, Laudon H, Winblad B, Lannfelt L, Lundkvist J, Naslund J (2003) APP intracellular domain formation and unaltered signaling in the presence of familial Alzheimer's disease mutations. Exp Cell Res 287:1-9

9. Kim HS, Kim EM, Lee JP, Park CH, Kim S, Seo JH, Chang KA, Yu E, Jeong SJ, Chong YH, Suh YH (2003) C-terminal fragments of amyloid precursor protein exert neurotoxicity by inducing glycogen synthase kinase-3beta expression. Faseb J 17:1951-1953 Epub 2003 Aug 1915

10. Wolfe MS, Kopan R (2004) Intramembrane proteolysis: theme and variations. Science 305:1119-1123

11. Kimberly WT, LaVoie MJ, Ostaszewski BL, Ye W, Wolfe MS, Selkoe DJ (2003) Gamma-secretase is a membrane protein complex comprised of presenilin, nicastrin, Aph-1, and Pen-2. Proc Natl Acad Sci USA 100:6382-6387

12. Yu G, Chen F, Levesque G, Nishimura M, Zhang DM, Levesque L, Rogaeva E, Xu D, Liang Y, Duthie M, St George-Hyslop PH, Fraser PE (1998) The presenilin 1 protein is a component of a high molecular weight intracellular complex that contains beta-catenin. J Biol Chem 273:16470-16475

13. Farmery MR, Tjernberg LO, Pursglove SE, Bergman A, Winblad B, Naslund J (2003) Partial purification and characterization of gamma-secretase from post-mortem human brain. J Biol Chem 278:24277-24284

14. Edbauer D, Winkler E, Haass C, Steiner H (2002) Presenilin and nicastrin regulate each other and determine amyloid beta-peptide production via complex formation. Proc Natl Acad Sci USA 99:8666-8671

15. Steiner H, Winkler E, Edbauer D, Prokop S, Basset G, Yamasaki A, Kostka M, Haass C (2002) PEN-2 is an integral component of the gamma-secretase complex required for coordinated expression of presenilin and nicastrin. J Biol Chem 277:39062-39065
16. Li T, Ma G, Cai H, Price DL, Wong PC (2003) Nicastrin is required for assembly of presenilin/gamma-secretase complexes to mediate Notch signaling and for processing and trafficking of beta-amyloid precursor protein in mammals. J Neurosci 23:3272-3277

17. Nyabi O, Bentahir M, Horre K, Herreman A, GottardiLittell N, Van Broeckhoven C, Merchiers P, Spittaels K, Annaert W, De Strooper B (2003) Presenilins mutated at Asp-257 or Asp-385 restore Pen-2 expression and Nicastrin glycosylation but remain catalytically inactive in the absence of wild type Presenilin. J Biol Chem 278:43430-43436

18. Li YM, Lai MT, Xu M, Huang Q, DiMuzio-Mower J, Sardana MK, Shi XP, Yin KC, Shafer JA, Gardell SJ (2000) Presenilin 1 is linked with gamma-secretase activity in the detergent solubilized state. Proc Natl Acad Sci USA 97:6138-6143

19. Francis R, McGrath G, Zhang J, Ruddy DA, Sym M, Apfeld J, Nicoll M, Maxwell M, Hai B, Ellis MC, Parks AL, Xu W, Li J, Gurney M, Myers RL, Himes CS, Hiebsch R, Ruble C, Nye JS, Curtis D (2002) Aph-1 and pen-2 are required for Notch pathway signaling, gamma-secretase cleavage of beta APP, and presenilin protein accumulation. Dev Cell 3:85-97

20. Lee SF, Shah S, Li H, Yu C, Han W, Yu G (2002) Mammalian APH-1 interacts with presenilin and nicastrin and is required for intramembrane proteolysis of amyloid-beta precursor protein and Notch. J Biol Chem 277:45013-45019

21. Gu Y, Chen F, Sanjo N, Kawarai T, Hasegawa H, Duthie M, Li W, Ruan X, Luthra A, Mount HT, Tandon A, Fraser PE, St George-Hyslop P (2003) APH-1 interacts with mature and immature forms of presenilins and nicastrin and may play a role in maturation of presenilin-nicastrin complexes. J Biol Chem 278:7374-7380

22. Hu Y, Fortini ME (2003) Different cofactor activities in gamma-secretase assembly: evidence for a nicastrin-Aph-1 subcomplex. J Cell Biol 161:685-690

23. Luo WJ, Wang H, Li H, Kim BS, Shah S, Lee HJ, Thinakaran G, Kim TW, Yu G, Xu H (2003) PEN-2 and APH1 coordinately regulate proteolytic processing of presenilin 1. J Biol Chem 278:7850-7854

24. Takasugi N, Tomita T, Hayashi I, Tsuruoka M, Niimura M, Takahashi Y, Thinakaran G, Iwatsubo T (2003) The role of presenilin cofactors in the gamma-secretase complex. Nature 422:438-441

25. Edbauer D, Winkler E, Regula JT, Pesold B, Steiner H, Haass C (2003) Reconstitution of gamma-secretase activity. Nat Cell Biol 5:486-488

26. Hayashi I, Urano Y, Fukuda R, Isoo N, Kodama T, Hamakubo T, Tomita T, Iwatsubo T (2004) Selective reconstitution and recovery of functional gamma-secretase complex on budded baculovirus particles. J Biol Chem 279:38040-38046

27. Zhang L, Lee J, Song L, Sun X, Shen J, Terracina G, Parker EM (2005) Characterization of the reconstituted gammasecretase complex from Sf9 cells co-expressing presenilin 1, nicastrin [correction of nacastrin], aph-1a, and pen-2. Biochemistry 44:4450-4457

28. Borchelt DR, Thinakaran G, Eckman CB, Lee MK, Davenport F, Ratovitsky T, Prada CM, Kim G, Seekins S, Yager D, Slunt HH, Wang R, Seeger M, Levey AI, Gandy SE, Copeland NG, Jenkins NA, Price DL, Younkin SG, Sisodia SS (1996) Familial Alzheimer's disease-linked presenilin 1 variants elevate Abeta1-42/1-40 ratio in vitro and in vivo. Neuron 17:1005-1013 
29. Lemere CA, Lopera F, Kosik KS, Lendon CL, Ossa J, Saido TC, Yamaguchi H, Ruiz A, Martinez A, Madrigal L, Hincapie L, Arango JC, Anthony DC, Koo EH, Goate AM, Selkoe DJ (1996) The E280A presenilin 1 Alzheimer mutation produces increased A beta 42 deposition and severe cerebellar pathology. Nat Med 2:1146-1150

30. Xia W, Zhang J, Kholodenko D, Citron M, Podlisny MB, Teplow DB, Haass C, Seubert P, Koo EH, Selkoe DJ (1997) Enhanced production and oligomerization of the 42-residue amyloid beta-protein by Chinese hamster ovary cells stably expressing mutant presenilins. J Biol Chem 272:7977-7982

31. De Strooper B, Saftig P, Craessaerts K, Vanderstichele H, Guhde G, Annaert W, Von Figura K, Van Leuven F (1998) Deficiency of presenilin-1 inhibits the normal cleavage of amyloid precursor protein. Nature 391:387-390

32. Wolfe MS, Xia W, Ostaszewski BL, Diehl TS, Kimberly WT, Selkoe DJ (1999) Two transmembrane aspartates in presenilin-1 required for presenilin endoproteolysis and gamma-secretase activity. Nature 398:513-517

33. Steiner H, Duff K, Capell A, Romig H, Grim MG, Lincoln S, Hardy J, Yu X, Picciano M, Fechteler K, Citron M, Kopan R, Pesold B, Keck S, Baader M, Tomita T, Iwatsubo T, Baumeister R, Haass C (1999) A loss of function mutation of presenilin-2 interferes with amyloid beta-peptide production and notch signaling. J Biol Chem 274:2866928673

34. Kimberly WT, Xia W, Rahmati T, Wolfe MS, Selkoe DJ (2000) The transmembrane aspartates in presenilin 1 and 2 are obligatory for gamma-secretase activity and amyloid beta-protein generation. J Biol Chem 275:3173-3178

35. Li YM, Xu M, Lai MT, Huang Q, Castro JL, DiMuzioMower J, Harrison T, Lellis C, Nadin A, Neduvelil JG, Register RB, Sardana MK, Shearman MS, Smith AL, Shi XP, Yin KC, Shafer JA, Gardell SJ (2000) Photoactivated gamma-secretase inhibitors directed to the active site covalently label presenilin 1. Nature 405:689-694

36. Esler WP, Kimberly WT, Ostaszewski BL, Diehl TS, Moore CL, Tsai JY, Rahmati T, Xia W, Selkoe DJ, Wolfe MS (2000) Transition-state analogue inhibitors of gamma-secretase bind directly to presenilin-1. Nat Cell Biol 2:428-434

37. Seiffert D, Bradley JD, Rominger CM, Rominger DH, Yang F, Meredith JE Jr, Wang Q, Roach AH, Thompson LA, Spitz SM, Higaki JN, Prakash SR, Combs AP, Copeland RA, Arneric SP, Hartig PR, Robertson DW, Cordell B, Stern AM, Olson RE, Zaczek R (2000) Presenilin-1 and 2 are molecular targets for gamma-secretase inhibitors. J Biol Chem 275:34086-34091

38. Verdile G, Martins RN, Duthie M, Holmes E, St. GeorgeHyslop PH, Fraser PE (2000) Inhibiting amyloid precursor protein C-terminal cleavage promotes an interaction with presenilin 1. J Biol Chem 275:20794-20798

39. Xia W, Ray WJ, Ostaszewski BL, Rahmati T, Kimberly WT, Wolfe MS, Zhang J, Goate AM, Selkoe DJ (2000) Presenilin complexes with the C-terminal fragments of amyloid precursor protein at the sites of amyloid betaprotein generation. Proc Natl Acad Sci USA 97:9299-9304

40. Annaert WG, Esselens C, Baert V, Boeve C, Snellings G, Cupers P, Craessaerts K, De Strooper B (2001) Interaction with telencephalin and the amyloid precursor protein predicts a ring structure for presenilins. Neuron 32:579-589

41. Liz MA, Sousa MM (2005) Deciphering cryptic proteases. Cell Mol Life Sci 62:989-1002

42. Wolfe MS (2003) The secretases of Alzheimer's disease. Curr Top Dev Biol 54:233-261
43. Xia W, Wolfe MS (2003) Intramembrane proteolysis by presenilin and presenilin-like proteases. J Cell Sci 116:28392844

44. Thinakaran G, Borchelt DR, Lee MK, Slunt HH, Spitzer L, Kim G, Ratovitsky T, Davenport F, Nordstedt C, Seeger M, Hardy J, Levey AI, Gandy SE, Jenkins NA, Copeland NG, Price DL, Sisodia SS (1996) Endoproteolysis of presenilin 1 and accumulation of processed derivatives in vivo. Neuron 17:181-190

45. Podlisny MB, Citron M, Amarante P, Sherrington R, Xia W, Zhang J, Diehl T, Levesque G, Fraser P, Haass C, Koo EH, Seubert P, St George-Hyslop P, Teplow DB, Selkoe DJ (1997) Presenilin proteins undergo heterogeneous endoproteolysis between Thr291 and Ala299 and occur as stable $\mathrm{N}$ - and C-terminal fragments in normal and Alzheimer brain tissue. Neurobiol Dis 3:325-337

46. Levitan D, Lee J, Song L, Manning R, Wong G, Parker E, Zhang L (2001) PS1 N- and C-terminal fragments form a complex that functions in APP processing and Notch signaling. Proc Natl Acad Sci USA 98:12186-12190

47. Laudon H, Mathews PM, Karlstrom H, Bergman A, Farmery MR, Nixon RA, Winblad B, Gandy SE, Lendahl U, Lundkvist J, Naslund J (2004) Co-expressed presenilin 1 NTF and CTF form functional gamma-secretase complexes in cells devoid of full-length protein. J Neurochem 89:44-53

48. Capell A, Grunberg J, Pesold B, Diehlmann A, Citron M, Nixon R, Beyreuther K, Selkoe DJ, Haass C (1998) The proteolytic fragments of the Alzheimer's disease-associated presenilin-1 form heterodimers and occur as a 100-150-kDa molecular mass complex. J Biol Chem 273:3205-3211

49. Seeger M, Nordstedt C, Petanceska S, Kovacs DM, Gouras GK, Hahne S, Fraser P, Levesque L, Czernik AJ, GeorgeHyslop PS, Sisodia SS, Thinakaran G, Tanzi RE, Greengard P, Gandy S (1997) Evidence for phosphorylation and oligomeric assembly of presenilin 1. Proc Natl Acad Sci USA 94:5090-5094

50. Steiner H, Capell A, Pesold B, Citron M, Kloetzel PM, Selkoe DJ, Romig H, Mendla K, Haass C (1998) Expression of Alzheimer's disease-associated presenilin-1 is controlled by proteolytic degradation and complex formation. J Biol Chem 273:32322-32331

51. Beher D, Elle C, Underwood J, Davis JB, Ward R, Karran E, Masters CL, Beyreuther K, Multhaup G (1999) Proteolytic fragments of Alzheimer's disease-associated presenilin 1 are present in synaptic organelles and growth cone membranes of rat brain. J Neurochem 72:1564-1573

52. Yu G, Chen F, Nishimura M, Steiner H, Tandon A, Kawarai T, Arawaka S, Supala A, Song YQ, Rogaeva E, Holmes E, Zhang DM, Milman P, Fraser P, Haass C, St. George-Hyslop P (2000) Mutation of conserved aspartates affect maturation of presenilin 1 and presenilin 2 complexes. Acta Neurol Scand Suppl 176:6-11

53. Cervantes S, Gonzalez-Duarte R, Marfany G (2001) Homodimerization of presenilin N-terminal fragments is affected by mutations linked to Alzheimer's disease. FEBS Lett 505:81-86

54. Schroeter EH, Ilagan MX, Brunkan AL, Hecimovic S, Li YM, Xu M, Lewis HD, Saxena MT, De Strooper B, Coonrod A, Tomita T, Iwatsubo T, Moore CL, Goate A, Wolfe MS, Shearman M, Kopan R (2003) A presenilin dimer at the core of the gamma-secretase enzyme: insights from parallel analysis of Notch 1 and APP proteolysis. Proc Natl Acad Sci USA 100:13075-13080 
55. Yu G, Nishimura M, Arawaka S, Levitan D, Zhang L, Tandon A, Song YQ, Rogaeva E, Chen F, Kawarai T, Supala A, Levesque L, Yu H, Yang DS, Holmes E, Milman P, Liang Y, Zhang DM, Xu DH, Sato C, Rogaev E, Smith M, Janus C, Zhang Y, Aebersold R, Farrer LS, Sorbi S, Bruni A, Fraser P, St. George-Hyslop P (2000) Nicastrin modulates presenilin-mediated notch/glp-1 signal transduction and betaAPP processing. Nature 407:48-54

56. Leem JY, Vijayan S, Han P, Cai D, Machura M, Lopes KO, Veselits ML, Xu H, Thinakaran G (2002) Presenilin 1 is required for maturation and cell surface accumulation of nicastrin. J Biol Chem 277:19236-19240

57. Tomita T, Katayama R, Takikawa R, Iwatsubo T (2002) Complex $\mathrm{N}$-glycosylated form of nicastrin is stabilized and selectively bound to presenilin fragments. FEBS Lett 520:117-121

58. Yang DS, Tandon A, Chen F, Yu G, Yu H, Arawaka S, Hasegawa H, Duthie M, Schmidt SD, Ramabhadran TV, Nixon RA, Mathews PM, Gandy SE, Mount HT, St. George-Hyslop P, Fraser PE (2002) Mature glycosylation and trafficking of nicastrin modulate its binding to presenilins. J Biol Chem 277:28135-28142

59. Chung HM, Struhl G (2001) Nicastrin is required for Presenilin-mediated transmembrane cleavage in Drosophila. Nat Cell Biol 3:1129-1132

60. $\mathrm{Hu} \mathrm{Y,} \mathrm{Ye} \mathrm{Y,} \mathrm{Fortini} \mathrm{ME} \mathrm{(2002)} \mathrm{Nicastrin} \mathrm{is} \mathrm{required} \mathrm{for}$ gamma-secretase cleavage of the Drosophila Notch receptor. Dev Cell 2:69-78

61. Lopez-Schier H, St Johnston D (2002) Drosophila nicastrin is essential for the intramembranous cleavage of notch. Dev Cell 2:79-89

62. Zhang T, Tran S, Clouser C, Pignoni F, Zhang YW, Luo WJ, Wang H, Lin P, Vetrivel KS, Liao F, Li F, Wong PC, Farquhar MG, Thinakaran G, and Xu H (2005) Nicastrin controls aspects of photoreceptor neuron specification and differentiation in the Drosophila eye Nicastrin is critical for stability and trafficking but not association of other presenilin/gamma-secretase components. Dev Dyn 234: 590-601

63. Shah S, Lee SF, Tabuchi K, Hao YH, Yu C, LaPlant Q, Ball H, Dann CE III, Sudhof T, Yu G (2005) Nicastrin functions as a gamma-secretase-substrate receptor. Cell 122:435-447

64. Berezovska O, Ramdya P, Skoch J, Wolfe MS, Bacskai BJ, Hyman BT (2003) Amyloid precursor protein associates with a nicastrin-dependent docking site on the presenilin 1gamma-secretase complex in cells demonstrated by fluorescence lifetime imaging. J Neurosci 23:4560-4566

65. Goutte C, Tsunozaki M, Hale VA, Priess JR (2002) APH-1 is a multipass membrane protein essential for the Notch signaling pathway in Caenorhabditis elegans embryos. Proc Natl Acad Sci USA 99:775-779

66. Shirotani K, Edbauer D, Prokop S, Haass C, Steiner H (2004) Identification of distinct gamma-secretase complexes with different APH-1 variants. J Biol Chem 279:4134041345

67. Ma G, Li T, Price DL, Wong PC (2005) APH-1a is the principal mammalian APH-1 isoform present in gammasecretase complexes during embryonic development. J Neurosci 25:192-198

68. Lee SF, Shah S, Yu C, Wigley WC, Li H, Lim M, Pedersen K, Han W, Thomas P, Lundkvist J, Hao YH, Yu G (2004) A conserved GXXXG motif in APH-1 is critical for assembly and activity of the gamma-secretase complex. J Biol Chem 279:4144-4152
69. Niimura M, Isoo N, Takasugi N, Tsuruoka M, Ui-Tei K, Saigo K, Morohashi Y, Tomita T, Iwatsubo T (2005) Aph-1 contributes to the stabilization and trafficking of the gamma-secretase complex through mechanisms involving intermolecular and intramolecular interactions. J Biol Chem 280:12967-12975

70. LaVoie MJ, Fraering PC, Ostaszewski BL, Ye W, Kimberly WT, Wolfe MS, Selkoe DJ (2003) Assembly of the gammasecretase complex involves early formation of an intermediate subcomplex of Aph-1 and nicastrin. J Biol Chem 278:37213-37222

71. Kim SH, Ikeuchi T, Yu C, Sisodia SS (2003) Regulated hyperaccumulation of presenilin-1 and the "gamma-secretase" complex. Evidence for differential intramembranous processing of transmembrane subatrates. J Biol Chem 278:33992-34002

72. Hansson EM, Stromberg K, Bergstedt S, Yu G, Naslund J, Lundkvist J, Lendahl U (2005) Aph-1 interacts at the cell surface with proteins in the active gamma-secretase complex and membrane-tethered Notch. J Neurochem 92:10101020

73. Urban S, Lee JR, Freeman M (2001) Drosophila rhomboid1 defines a family of putative intramembrane serine proteases. Cell 107:173-182

74. De Strooper B (2003) Aph-1, Pen-2, and Nicastrin with Presenilin generate an active gamma-secretase complex. Neuron 38:9-12

75. Morais VA, Crystal AS, Pijak DS, Carlin D, Costa J, Lee VM, Doms RW (2003) The transmembrane domain region of nicastrin mediates direct interactions with APH-1 and the gamma-secretase complex. J Biol Chem 278:4328443291

76. Bergman A, Hansson EM, Pursglove SE, Farmery MR, Lannfelt L, Lendahl U, Lundkvist J, Naslund J (2004) Pen-2 is sequestered in the endoplasmic reticulum and subjected to ubiquitylation and proteasome-mediated degradation in the absence of presenilin. J Biol Chem 279:16744-16753

77. Crystal AS, Morais VA, Fortna RR, Carlin D, Pierson TC, Wilson CA, Lee VM, Doms RW (2004) Presenilin modulates Pen-2 levels posttranslationally by protecting it from proteasomal degradation. Biochemistry 43:3555-3563

78. Hasegawa H, Sanjo N, Chen F, Gu YJ, Shier C, Petit A, Kawarai T, Katayama T, Schmidt SD, Mathews PM, Schmitt-Ulms G, Fraser PE, St. George-Hyslop P (2004) Both the sequence and length of the $\mathrm{C}$ terminus of PEN-2 are critical for intermolecular interactions and function of presenilin complexes. J Biol Chem 279:46455-46463

79. Watanabe N, Tomita T, Sato C, Kitamura T, Morohashi Y, Iwatsubo T (2005) Pen-2 is incorporated into the gammasecretase complex through binding to transmembrane domain 4 of presenilin 1. J Biol Chem 280:41967-41975

80. Kim SH, Sisodia SS (2005) Evidence that the "NF" motif in transmembrane domain 4 of presenilin 1 is critical for binding with PEN-2. J Biol Chem 280:41953-41966

81. Prokop S, Haass C, Steiner H (2005) Length and overall sequence of the PEN-2 C-terminal domain determines its function in the stabilization of presenilin fragments. J Neurochem 94:57-62

82. Chen F, Hasegawa H, Schmitt-Ulms G, Kawarai T, Bohm C, Katayama T, Gu Y, Sanjo N, Glista M, Rogaeva E, Wakutani Y, Pardossi-Piquard R, Ruan X, Tandon A, Checler F, Marambaud P, Hansen K, Westaway D, St. George-Hyslop P, Fraser P (2006) TMP21 is a presenilin complex component that modulates gamma-secretase but not epsilon-secretase activity. Nature 440:1208-1212 
83. Blum R, Feick P, Puype M, Vandekerckhove J, Klengel R, Nastainczyk W, Schulz I (1996) Tmp21 and p24A, two type I proteins enriched in pancreatic microsomal membranes, are members of a protein family involved in vesicular trafficking. J Biol Chem 271:17183-17189

84. Barr FA, Preisinger C, Kopajtich R, Korner R (2001) Golgi matrix proteins interact with p24 cargo receptors and aid their efficient retention in the Golgi apparatus. J Cell Biol 155:885-891

85. Levy-Lahad E, Wasco W, Poorkaj P, Romano DM, Oshima J, Pettingell WH, Yu CE, Jondro PD, Schmidt SD, Wang K, et al (1995) Candidate gene for the chromosome 1 familial Alzheimer's disease locus. Science 269:973-977

86. Rogaev EI, Sherrington R, Rogaeva EA, Levesque G, Ikeda M, Liang Y, Chi H, Lin C, Holman K, Tsuda T, et al (1995) Familial Alzheimer's disease in kindreds with missense mutations in a gene on chromosome 1 related to the Alzheimer's disease type 3 gene. Nature 376:775-778

87. Shen J, Bronson RT, Chen DF, Xia W, Selkoe DJ, Tonegawa S (1997) Skeletal and CNS defects in Presenilin1-deficient mice. Cell 89:629-639

88. Wong PC, Zheng H, Chen H, Becher MW, Sirinathsinghji DJ, Trumbauer ME, Chen HY, Price DL, Van der Ploeg LH, Sisodia SS (1997) Presenilin 1 is required for Notch1 and DII1 expression in the paraxial mesoderm. Nature 387:288-292

89. Herreman A, Hartmann D, Annaert W, Saftig P, Craessaerts K, Serneels L, Umans L, Schrijvers V, Checler F, Vanderstichele H, Baekelandt V, Dressel R, Cupers P, Huylebroeck D, Zwijsen A, Van Leuven F, De Strooper B (1999) Presenilin 2 deficiency causes a mild pulmonary phenotype and no changes in amyloid precursor protein processing but enhances the embryonic lethal phenotype of presenilin 1 deficiency. Proc Natl Acad Sci USA 96:1187211877

90. Rozmahel R, Mount HT, Chen F, Nguyen V, Huang J, Erdebil S, Liauw J, Yu G, Hasegawa H, Gu Y, Song YQ, Schmidt SD, Nixon RA, Mathews PM, Bergeron C, Fraser P, Westaway D, St. George-Hyslop P (2002) Alleles at the Nicastrin locus modify presenilin 1-deficiency phenotype. Proc Natl Acad Sci USA 99:14452-14457

91. Lai MT, Chen E, Crouthamel MC, DiMuzio-Mower J, Xu M, Huang Q, Price E, Register RB, Shi XP, Donoviel DB, Bernstein A, Hazuda D, Gardell SJ, Li YM (2003) Presenilin-1 and presenilin-2 exhibit distinct yet overlapping gamma-secretase activities. J Biol Chem 278:2247522481

92. Stromberg K, Hansson EM, Laudon H, Bergstedt S, Naslund J, Lundkvist J, Lendahl U (2005) gamma-secretase complexes containing $\mathrm{N}$ - and $\mathrm{C}$-terminal fragments of different presenilin origin retain normal gamma-secretase activity. J Neurochem 95:880-890

93. Mastrangelo P, Mathews PM, Chishti MA, Schmidt SD, Gu Y, Yang J, Mazzella MJ, Coomaraswamy J, Horne P, Strome B, Pelly H, Levesque G, Ebeling C, Jiang Y, Nixon RA, Rozmahel R, Fraser PE, St. George-Hyslop P, Carlson GA, Westaway D (2005) Dissociated phenotypes in presenilin transgenic mice define functionally distinct gammasecretases. Proc Natl Acad Sci USA 102:8972-8977

94. Buxbaum JD, Choi EK, Luo Y, Lilliehook C, Crowley AC, Merriam DE, Wasco W (1998) Calsenilin: a calcium-binding protein that interacts with the presenilins and regulates the levels of a presenilin fragment. Nat Med 4:1177-1181

95. Buxbaum JD (2004) A role for calsenilin and related proteins in multiple aspects of neuronal function. Biochem Biophys Res Commun 322:1140-1144
96. Choi EK, Zaidi NF, Miller JS, Crowley AC, Merriam DE, Lilliehook C, Buxbaum JD, Wasco W (2001) Calsenilin is a substrate for caspase- 3 that preferentially interacts with the familial Alzheimer's disease-associated C-terminal fragment of presenilin 2. J Biol Chem 276:19197-19204

97. Leissring MA, Yamasaki TR, Wasco W, Buxbaum JD, Parker I, LaFerla FM (2000) Calsenilin reverses presenilinmediated enhancement of calcium signaling. Proc Natl Acad Sci USA 97:8590-8593

98. Lilliehook C, Chan S, Choi EK, Zaidi NF, Wasco W, Mattson MP, Buxbaum JD (2002) Calsenilin enhances apoptosis by altering endoplasmic reticulum calcium signaling. Mol Cell Neurosci 19:552-559

99. Jo DG, Chang JW, Hong HS, Mook-Jung I, Jung YK (2003) Contribution of presenilin/gamma-secretase to calsenilinmediated apoptosis. Biochem Biophys Res Commun 305:62-66

100. Jo DG, Kim MJ, Choi YH, Kim IK, Song YH, Woo HN, Chung CW, Jung YK (2001) Pro-apoptotic function of calsenilin/DREAM/KChIP3. Faseb J 15:589-591

101. Jo DG, Jang J, Kim BJ, Lundkvist J, Jung YK (2005) Overexpression of calsenilin enhances gamma-secretase activity. Neurosci Lett 378:59-64

102. Lilliehook C, Bozdagi O, Yao J, Gomez-Ramirez M, Zaidi NF, Wasco W, Gandy S, Santucci AC, Haroutunian V, Huntley GW, Buxbaum JD (2003) Altered Abeta formation and long-term potentiation in a calsenilin knock-out. J Neurosci 23:9097-9106

103. Borg JP, Yang Y, De Taddeo-Borg M, Margolis B, Turner RS (1998) The X11alpha protein slows cellular amyloid precursor protein processing and reduces Abeta40 and Abeta42 secretion. J Biol Chem 273:14761-14766

104. Sastre M, Turner RS, Levy E (1998) X11 interaction with beta-amyloid precursor protein modulates its cellular stabilization and reduces amyloid beta-protein secretion. J Biol Chem 273:22351-22357

105. McLoughlin DM, Irving NG, Brownlees J, Brion JP, Leroy K, Miller CC (1999) Mint2/X11-like colocalizes with the Alzheimer's disease amyloid precursor protein and is associated with neuritic plaques in Alzheimer's disease. Eur J Neurosci 11:1988-1994

106. Tomita S, Ozaki T, Taru H, Oguchi S, Takeda S, Yagi Y, Sakiyama S, Kirino Y, Suzuki T (1999) Interaction of a neuron-specific protein containing PDZ domains with Alzheimer's amyloid precursor protein. J Biol Chem 274:2243-2254

107. McLoughlin DM, Miller CC (1996) The intracellular cytoplasmic domain of the Alzheimer's disease amyloid precursor protein interacts with phosphotyrosine-binding domain proteins in the yeast two-hybrid system. FEBS Lett 397:197-200

108. Zhang Z, Lee CH, Mandiyan V, Borg JP, Margolis B, Schlessinger J, Kuriyan J (1997) Sequence-specific recognition of the internalization motif of the Alzheimer's amyloid precursor protein by the X11 PTB domain. Embo J 16:6141-6150

109. Tanahashi H, Tabira T (1999) X11L2, a new member of the X11 protein family, interacts with Alzheimer's beta-amyloid precursor protein. Biochem Biophys Res Commun 255:663667

110. Lau KF, McLoughlin DM, Standen C, Miller CC (2000) $\mathrm{X} 11$ alpha and X11 beta interact with presenilin-1 via their PDZ domains. Mol Cell Neurosci 16:557-565

111. Araki Y, Tomita S, Yamaguchi H, Miyagi N, Sumioka A, Kirino Y, Suzuki T (2003) Novel cadherin-related membrane proteins, Alcadeins, enhance the X11-like proteinmediated stabilization of amyloid beta-protein precursor metabolism. J Biol Chem 278:49448-49458 
112. Ray WJ, Yao M, Mumm J, Schroeter EH, Saftig P, Wolfe M, Selkoe DJ, Kopan R, Goate AM (1999) Cell surface presenilin-1 participates in the gamma-secretase-like proteolysis of Notch. J Biol Chem 274:36801-36807

113. Sastre M, Steiner H, Fuchs K, Capell A, Multhaup G, Condron MM, Teplow DB, Haass C (2001) Presenilindependent gamma-secretase processing of beta-amyloid precursor protein at a site corresponding to the S3 cleavage of Notch. EMBO Rep 2:835-841

114. Roncarati R, Sestan N, Scheinfeld MH, Berechid BE, Lopez PA, Meucci O, McGlade JC, Rakic P, D'Adamio L (2002) The gamma-secretase-generated intracellular domain of beta-amyloid precursor protein binds Numb and inhibits Notch signaling. Proc Natl Acad Sci USA 99:71027107

115. Okochi M, Steiner H, Fukumori A, Tanii H, Tomita T, Tanaka T, Iwatsubo T, Kudo T, Takeda M, Haass C (2002) Presenilins mediate a dual intramembranous gamma-secretase cleavage of Notch-1. Embo J 21:5408-5416

116. Berezovska O, Jack C, Deng A, Gastineau N, Rebeck GW, Hyman BT (2001) Notch1 and amyloid precursor protein are competitive substrates for presenilin1-dependent gamma-secretase cleavage. J Biol Chem 276:30018-30023

117. Kimberly WT, Esler WP, Ye W, Ostaszewski BL, Gao J, Diehl T, Selkoe DJ, Wolfe MS (2003) Notch and the amyloid precursor protein are cleaved by similar gamma-secretase(s). Biochemistry 42:137-144

118. Lleo A, Berezovska O, Ramdya P, Fukumoto H, Raju S, Shah T, Hyman BT (2003) Notch1 competes with the amyloid precursor protein for gamma-secretase and downregulates presenilin-1 gene expression. J Biol Chem 278:47370-47375

119. Lleo A, Waldron E, von Arnim CA, Herl L, Tangredi MM, Peltan ID, Strickland DK, Koo EH, Hyman BT, Pietrzik CU, Berezovska O (2005) Low density lipoprotein receptorrelated protein (LRP) interacts with presenilin 1 and is a competitive substrate of the amyloid precursor protein (APP) for gamma-secretase. J Biol Chem 280:27303-27309

120. Ogura T, Mio K, Hayashi I, Miyashita H, Fukuda R, Kopan R, Kodama T, Hamakubo T, Iwastubo T, Tomita T, Sato C (2006) Three-dimensional structure of the gamma-secretase complex. Biochem Biophys Res Commun 343:525-534

121. Lazarov VK, Fraering PC, Ye W, Wolfe MS, Selkoe DJ, Li H (2006) Electron microscopic structure of purified, active gamma-secretase reveals an aqueous intramembrane chamber and two pores. Proc Natl Acad Sci USA 103:6889-6894

122. Fraering PC, Ye W, LaVoie MJ, Ostaszewski BL, Selkoe DJ, Wolfe MS (2005) Gamma-secretase substrate selectivity can be modulated directly via interaction with a nucleotidebinding site. J Biol Chem 280:41987-41996

123. Shirotani K, Edbauer D, Kostka M, Steiner H, Haass C (2004) Immature nicastrin stabilizes APH-1 independent of PEN-2 and presenilin: identification of nicastrin mutants that selectively interact with APH-1. J Neurochem 89:15201527

124. Georgakopoulos A, Marambaud P, Friedrich VL Jr, Shioi J, Efthimiopoulos S, Robakis NK (2000) Presenilin-1: a component of synaptic and endothelial adherens junctions. Ann NY Acad Sci 920:209-214

125. Katayama T, Imaizumi K, Sato N, Miyoshi K, Kudo T, Hitomi J, Morihara T, Yoneda T, Gomi F, Mori Y, Nakano Y, Takeda J, Tsuda T, Itoyama Y, Murayama O, Takashima A, St. George-Hyslop P, Takeda M, Tohyama M (1999) Presenilin-1 mutations downregulate the signalling pathway of the unfolded-protein response. Nat Cell Biol 1:479-485
126. Niwa M, Sidrauski C, Kaufman RJ, Walter P (1999) A role for presenilin-1 in nuclear accumulation of Ire1 fragments and induction of the mammalian unfolded protein response. Cell 99:691-702

127. Zhang W, Han SW, McKeel DW, Goate A, Wu JY (1998) Interaction of presenilins with the filamin family of actinbinding proteins. J Neurosci 18:914-922

128. Alberici A, Moratto D, Benussi L, Gasparini L, Ghidoni R, Gatta LB, Finazzi D, Frisoni GB, Trabucchi M, Growdon JH, Nitsch RM, Binetti G (1999) Presenilin 1 protein directly interacts with Bcl-2. J Biol Chem 274: 30764-30769

129. Passer BJ, Pellegrini L, Vito P, Ganjei JK, D'Adamio L (1999) Interaction of Alzheimer's presenilin-1 and presenilin-2 with $\mathrm{Bcl}-\mathrm{X}(\mathrm{L})$. A potential role in modulating the threshold of cell death. J Biol Chem 274:24007-24013

130. Stabler SM, Ostrowski LL, Janicki SM, Monteiro MJ (1999) A myristoylated calcium-binding protein that preferentially interacts with the Alzheimer's disease presenilin 2 protein. J Cell Biol 145:1277-1292

131. Morohashi Y, Hatano N, Ohya S, Takikawa R, Watabiki T, Takasugi N, Imaizumi Y, Tomita T, Iwatsubo T (2002) Molecular cloning and characterization of CALP/KChIP4, a novel EF-hand protein interacting with presenilin 2 and voltage-gated potassium channel subunit Kv4. J Biol Chem 277:14965-14975

132. Johnsingh AA, Johnston JM, Merz G, Xu J, Kotula L, Jacobsen JS, Tezapsidis N (2000) Altered binding of mutated presenilin with cytoskeleton-interacting proteins. FEBS Lett 465:53-58

133. Tanahashi H, Tabira T (2000) Alzheimer's disease-associated presenilin 2 interacts with DRAL, an LIM-domain protein. Hum Mol Genet 9:2281-2289

134. Kang DE, Yoon IS, Repetto E, Busse T, Yermian N, Ie L, Koo EH (2005) Presenilins mediate phosphatidylinositol 3kinase/AKT and ERK activation via select signaling receptors. Selectivity of PS2 in platelet-derived growth factor signaling. J Biol Chem 280:31537-31547

135. Wang HQ, Nakaya Y, Du Z, Yamane T, Shirane M, Kudo T, Takeda M, Takebayashi K, Noda Y, Nakayama KI, Nishimura M (2005) Interaction of presenilins with FKBP38 promotes apoptosis by reducing mitochondrial Bcl-2. Hum Mol Genet 14:1889-1902

136. Smine A, Xu X, Nishiyama K, Katada T, Gambetti P, Yadav SP, Wu X, Shi YC, Yasuhara S, Homburger V, Okamoto T (1998) Regulation of brain G-protein go by Alzheimer's disease gene presenilin-1. J Biol Chem 273: 16281-16288

137. Takashima A, Murayama M, Murayama O, Kohno T, Honda T, Yasutake K, Nihonmatsu N, Mercken M, Yamaguchi H, Sugihara S, Wolozin B (1998) Presenilin 1 associates with glycogen synthase kinase-3beta and its substrate tau. Proc Natl Acad Sci USA 95:9637-9641

138. Van Gassen G, C De Jonghe, Pype S, Van Criekinge W, Julliams A, Vanderhoeven I, Woodrow S, Beyaert R, Huylebroeck D, Van Broeckhoven C (1999) Alzheimer's disease associated presenilin 1 interacts with HC5 and ZETA, subunits of the catalytic 20S proteasome. Neurobiol Dis 6:376-391

139. Zhang SX, Guo Y, Boulianne GL (2001) Identification of a novel family of putative methyltransferases that interact with human and Drosophila presenilins. Gene 280:135-144

140. Chen Q, Kimura H, Schubert D (2002) A novel mechanism for the regulation of amyloid precursor protein metabolism. J Cell Biol 158:79-89 
141. Gupta S, Singh R, Datta P, Zhang Z, Orr C, Lu Z, Dubois G, Zervos AS, Meisler MH, Srinivasula SM, FernandesAlnemri T, Alnemri ES (2004) The C-terminal tail of presenilin regulates $\mathrm{Omi} / \mathrm{HtrA} 2$ protease activity. J Biol Chem 279:45844-45854

142. Zhou Y, Zhang W, Easton R, Ray JW, Lampe P, Jiang Z, Brunkan AL, Goate A, Johnson EM, Wu JY (2002) Presenilin-1 protects against neuronal apoptosis caused by its interacting protein PAG. Neurobiol Dis 9:126-138

143. Pellegrini L, Passer BJ, Canelles M, Lefterov I, Ganjei JK, Fowlkes BJ, Koonin EV, D'Adamio L (2001) PAMP and PARL, two novel putative metalloproteases interacting with the $\mathrm{COOH}$-terminus of Presenilin-1 and -2. J Alzheimers Dis 3:181-190

144. Kang DE, Soriano S, Xia X, Eberhart CG, De Strooper B, Zheng H, Koo EH (2002) Presenilin couples the paired phosphorylation of beta-catenin independent of axin: implications for beta-catenin activation in tumorigenesis. Cell 110:751-762

145. Raurell I, Castano J, Franci C, Garcia de Herreros A, Dunach M (2006) Presenilin-1 interacts with plakoglobin and enhances plakoglobin-Tcf-4 association. Implications for the regulation of beta-catenin/Tcf-4-dependent transcription. J Biol Chem 281:1401-1411

146. Cai D, Netzer WJ, Zhong M, Lin Y, Du G, Frohman M, Foster DA, Sisodia SS, Xu H, Gorelick FS, Greengard P (2006) Presenilin-1 uses phospholipase D1 as a negative regulator of beta-amyloid formation. Proc Natl Acad Sci USA 103:1941-1946

147. Xu X, Shi Y, Wu X, Gambetti P, Sui D, Cui MZ (1999) Identification of a novel PSD-95/Dlg/ZO-1 (PDZ)-like protein interacting with the $\mathrm{C}$ terminus of presenilin-1. $\mathrm{J}$ Biol Chem 274:32543-32546

148. Imafuku I, Masaki T, Waragai M, Takeuchi S, Kawabata M, Hirai S, Ohno S, Nee LE, Lippa CF, Kanazawa I, Imagawa M, Okazawa H (1999) Presenilin 1 suppresses the function of c-Jun homodimers via interaction with QM/Jif-1. J Cell Biol 147:121-134

149. Dumanchin C, Czech C, Campion D, Cuif MH, Poyot T, Martin C, Charbonnier F, Goud B, Pradier L, Frebourg T (1999) Presenilins interact with Rab11, a small GTPase involved in the regulation of vesicular transport. Hum Mol Genet 8:1263-1269

150. Scheper W, Zwart R, Sluijs P, Annaert W, Gool WA, Baas F (2000) Alzheimer's presenilin 1 is a putative membrane receptor for rab GDP dissociation inhibitor. Hum Mol Genet 9:303-310

151. Takeda T, Asahi M, Yamaguchi O, Hikoso S, Nakayama H, Kusakari Y, Kawai M, Hongo K, Higuchi Y, Kashiwase K, Watanabe T, Taniike M, Nakai A, Nishida K, Kurihara S, Donoviel DB, Bernstein A, Tomita T, Iwatsubo T, Hori M, Otsu K (2005) Presenilin 2 regulates the systolic function of heart by modulating $\mathrm{Ca}^{2+}$ signaling. Faseb J 19:2069-2071

152. Li J, Pauley AM, Myers RL, Shuang R, Brashler JR, Yan R, Buhl AE, Ruble C, Gurney ME (2002) SEL-10 interacts with presenilin 1, facilitates its ubiquitination, and alters Abeta peptide production. J Neurochem 82:1540-1548
153. Pack-Chung E, Meyers MB, Pettingell WP, Moir RD, Brownawell AM, Cheng I, Tanzi RE, Kim TW (2000) Presenilin 2 interacts with sorcin, a modulator of the ryanodine receptor. J Biol Chem 275:14440-14445

154. Smith SK, Anderson HA, Yu G, Robertson AG, Allen SJ, Tyler SJ, Naylor RL, Mason G, Wilcock GW, Roche PA, Fraser PE, Dawbarn D (2000) Identification of syntaxin 1A as a novel binding protein for presenilin-1. Brain Res Mol Brain Res 78:100-107

155. Suga K, Saito A, Tomiyama T, Mori H, Akagawa K (2005) Syntaxin 5 interacts specifically with presenilin holoproteins and affects processing of betaAPP in neuronal cells. J Neurochem 94:425-439

156. Suga K, Tomiyama T, Mori H, Akagawa K (2004) Syntaxin 5 interacts with presenilin holoproteins, but not with their $\mathrm{N}$ - or C-terminal fragments, and affects beta-amyloid peptide production. Biochem J 381:619-628

157. Prihar G, Gonzalez de Chavez F, Baker M, Crook R, McGowan E, Grover A, Hardy J, Hutton M (1999) A novel candidate presenilin-1 interacting protein containing tetratricopeptide repeats. Neuroreport 10:1409-1415

158. Mah AL, Perry G, Smith MA, Monteiro MJ (2000) Identification of ubiquilin, a novel presenilin interactor that increases presenilin protein accumulation. J Cell Biol 151:847-862

159. Massey LK, Mah AL, Ford DL, Miller J, Liang J, Doong H, Monteiro MJ (2004) Overexpression of ubiquilin decreases ubiquitination and degradation of presenilin proteins. J Alzheimers Dis 6:79-92

160. Massey LK, Mah AL, Monteiro MJ (2005) Ubiquilin regulates presenilin endoproteolysis and modulates gammasecretase components, Pen-2 and nicastrin. Biochem J 391:513-525

161. Zhou J, Liyanage U, Medina M, Ho C, Simmons AD, Lovett M, Kosik KS (1997) Presenilin 1 interaction in the brain with a novel member of the Armadillo family. Neuroreport 8:2085-2090

162. Levesque G, Yu G, Nishimura M, Zhang DM, Levesque L, Yu H, Xu D, Liang Y, Rogaeva E, Ikeda M, Duthie M, Murgolo N, Wang L, VanderVere P, Bayne ML, Strader CD, Rommens JM, Fraser PE, P St. George-Hyslop (1999) Presenilins interact with armadillo proteins including neural-specific plakophilin-related protein and beta-catenin. J Neurochem 72:999-1008

163. Stahl B, Diehlmann A, Sudhof TC (1999) Direct interaction of Alzheimer's disease-related presenilin 1 with armadillo protein p0071. J Biol Chem 274:9141-9148

164. Shinozaki K, Maruyama K, Kume H, Tomita T, Saido TC, Iwatsubo T, Obata K (1998) The presenilin 2 loop domain interacts with the mu-calpain C-terminal region. Int $\mathrm{J}$ Mol Med 1:797-799

165. Periz G, Fortini ME (2004) Functional reconstitution of gamma-secretase through coordinated expression of presenilin, nicastrin, Aph-1, and Pen-2. J Neurosci Res 77:309322 